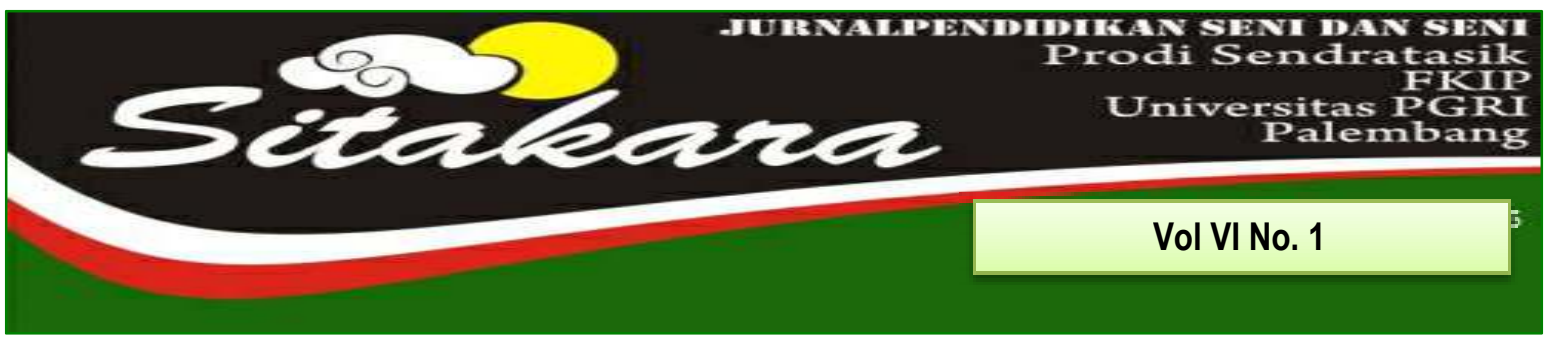

PERTUNJUKAN SOLIS MARIMBA DENGAN REPERTOAR THE VARIANTIONS ON THEME (FROM THE MALAY'S "PUCUK PISANG")

(Fery Herdianto)

BUKIT SIGUNTANG DALAM PENGEMBANGAN KONSEP RUANG KOREOGRAFI $\quad$ 13-26 LINGKUNGAN TARI

(Rully Rochayati, Eva Dina Chairunisa)

APLIKASI SIBELIUS SEBAGAI MEDIA PEMBELAJARAN DALAM MENULIS NOTASI MUSIK BERMAS

(Dedy Firmansyah \& Nugroho NAD)

PENGARUH MODEL PEMBELAJARAN EXPLICIT INSTRUCTION PADA 40-54 PEMBELAJARAN TARI DAERAH

(Treny Hera \& Efita Elvandari)

SIMBOLISASI ORNAMEN NAGA PADA PEMBATAS JALAN DI PALEMBANG (Decky Kunian \& A.Heryanto)

PENGARUH MODEL PEMBELAJARAN INSIDE-OUTSIDE-CIRCLE (IOC) TERHADAP WRITING SKILL DALAM TEKS MENULIS DRAMA DI SMP SETIA NEGARA PALEMBANG

(Sri Wahyu Indrawati \& Yuspar Uzer)

PEMANFAATAN TEKNOLOGI MULTIMEDIA DALAM PEMBELAJARAN MUSIK DI $79-87$ SMP N 1 PALEMBANG

(Novdaly Fillamenta \& Yuliza Aryani)

BENTUK PENYAJIAN ORKES GAMBUS SANGGAR MOZAIG PADA ACARA PERNIKAHAN ADAT ARAB PALEMBANG

(Auzy Madona Adoma)

PENINGKATAN KEMAMPUAN MEMBACA TEKS DRAMA DENGAN 100-111 MENGGUNAKAN METODE SPEED READING PADA PEMBELAJARAN BAHASA INDONESIA UNTUK SISWA SMPN 16 PALEMBANG (Wandiyo)

PELAKSANAAN EVALUASI PEMBELAJARAN SENI BUDAYA DI SMP 1 JEKULO 112-123 KUDUS PADA MASA PANDEMI COVID-19

M.Panji Wahyu Mukti \& Wahyu Lestari 
1. Naskah berbahasa Indonesia bertemakan Seni Budaya yang meliputi hasil penelitian pengajaran seni budaya, cabang seni, dan kebudayaan.

2. Naskah harus asli dan belum pernah dimuat dalam media lain. Naskah dapat berupa hasil penelitian perorangan atau kelompok.

3. Naskah ditulis dengan cara-cara yang sesuai dengan ketentuan penulisan artikel ilmiah menggunakan bahasa Indonesia yang baku, berupa ketikan, beserta soft line dalam CD-RW atau dengan mengirimkan email pada redaksi Jurnal SITARARA dengan alamat email: jurnalsitakarasendratasik@yahoo.com, spasi 1,5 jenis huruf Arrial Narrow ukuran 12, dengan panjang naskah antara 8-15 halaman pada kertas A4.

4. Artikel hasil penelitian memuat:

JUDUL

Nama Penulis

Abstrak

A. Pendahuluan

B. METODE PENELITIAN

C. HASIL DAN PEMBAHASAN

D. SIMPULAN
: XXX (HURUF KAPITAL)

: (disertai jabatan dan institusi)

: (Bahasa Indonesia yang memuat 100150 kata diikuti kata kunci, dengan jenis huruf Arrial Narrow dan ukuran huruf 11 spasi tunggal serta dicetak miring)

: (Memuat latar belakang masalah, tinjauan pustaka secara ringkas, masalah penelitian dan tujuan penelitian)

: (Berisi simpulan)

5. Artikel kajian konseptual memuat:

JUDUL

Nama Penulis

Abstrak

\section{: XXX (HURUF KAPITAL)}

: (disertai jabatan dan institusi)

: (Bahasa Indonesia yang memuat 100150 kata diikuti kata kunci, dengan jenis huruf Arrial Narrow dan ukuran huruf 11 serta dicetak miring)

PENDAHULUAN
: (Memuat latar belakang masalah, tinjauan pustaka secara ringkas, masalah penelitian dan tujuan penelitian) 
Sub Judul

Sub Judul

SIMPULAN

DAFTAR PUSTAKA
: Sesuai dengan kebutuhan (tanpa numbering)

: (Berisi simpulan dan saran)

: (Berisi pustaka yang dirujuk dalam uraian naskah

6. Referensi sumber dalam teks artikel ditulis dengan menggunakan side note, contoh: (Jalalluddin, 1991:79); (Taufik, 2005;350); (Hamid dan Madjid, 2011:43). Sementara penulisan daftar pustaka disusun dengan ketentuan. Nama Pengarang. Tahun Terbit. Judul (dicetak miring). Kota Terbit: Nama Penerbit. Contoh: Koentjaraningrat. 2010. Manusia dan Kebudayaan Di Indonesia. Jakarta: Djambatan.

Daftar pustaka hanya memuat pustaka/sumber yang dirujuk dalam uraian dan disusun menurut abjad, tanpa nomor urut.

7. Naskah yang dimuat akan disunting kembali oleh redaksi tanpa mengubah isinya.

8. Naskah yang ditolak (tidak bisa dimuat) akan dikirim kembali ke penulis dengan pemberitahuan tertulis dari redaksi atau alamat email.

9. Penulis yang naskahnya dimuat akan mendapatkan 1 (satu) majalah nomor yang bersangkutan.

10. Contact Person: Treny Hera (085357344704) dan Mainur (081373165553). 


\title{
PENGARUH MODEL PEMBELAJARAN INSIDE-OUTSIDE-CIRCLE (IOC) TERHADAP WRITING SKILL DALAM TEKS MENULIS DRAMA DI SMP SETIA NEGARA PALEMBANG
}

\author{
Oleh: \\ Sri Wahyu Indrawati ${ }^{1}$ \\ Yuspar Uzer ${ }^{2}$ \\ (Dosen FKIP Universitas PGRI Palembang) \\ Email: sriwahyuindrawati@gmail.com
}

\begin{abstract}
ABSTRAK
Penelitian ini bertujuan untuk mengetahui ada atau tidaknya pengaruh yang signifikan Pengaruh model pembelajaran IOC (inside-outside-circle) terhadap writing skill dalam teks drama. Metode penelitian yang digunakan dalam penelitian ini adalah metode eksperimen model Posttest-Only Control Design dengan membagi sampel mejadi dua kelompok yaitu kelompok eksperimen dan kelompok kontrol. Tes yang digunakan dalam penelitian ini yaitu tes akhir yang berebentuk esay dengan satu soal. Teknik analisis data yang digunakan dalam penelitian ini yaitu menggunakan rumus statistk uji-t. Berdasarkan tabel distribusi $-\mathrm{t}$ dengan $\mathrm{dk}=n_{1}+n_{2}-2=30+25-2=53$ dan a $=$ 0,05 , diidapat $t_{\text {hitung }}=3,38$ dan $t_{\text {tabel }}=1,67412$. Hal ini menunjukkan bahwa $t_{\text {hitung }} \geq t_{\text {tabel }}$ atau 3,38 $\geq 1,67412$. Dengan demikian dapat dikatakan bahwa $\mathrm{H}_{\mathrm{o}}$ ditolak dan $\mathrm{H}_{\mathrm{a}}$ diterima, berarti terdapat pengaruh yang signifikan dalam Penerapan model pembelajaran IOC (inside-outsidecircle) terhadap writing skill dalam teks drama di SMP Setia Negara Palembang.
\end{abstract}

Kata Kunci : Cerita Pendek, Inside-Outside-Circle (IOC)

\section{A. PENDAHULUAN}

Pada pembelajaran Bahasa Inggris, menulis merupakan salah satu keterampilan dari empat keterampilan. Berdasarkan tingkatnya, menulis berada pada urutan keempat setelah keterampilan menyimak, berbicara, dan membaca. Menulis diartikan sebagai kegiatan melahirkan pikiran dan perasaan. Selain itu, Menulis merupakan suatu kegiatan yang produktif dan ekspresif (Tarigan, 2008).
Namun keterampilan menulis masih kurang diminati oleh siswa disebabkan kurang minat dan latihan. Pembelajaran menulis yang dilakukan guru selama ini terlampau berorientasi pada produk (hasil) dan mengabaikan proses. Faktor inilah yang menyebabkan guru selalu mendominasi kelas, sehingga seringkali menjadikan suasana yang terfokus pada satu arah. Siswa kurang diberi kesempatan untuk menuliskan kreativitasnya dan menjadi lebih pasif. Menurut Yunus S. d., (2009) 
menulis dapat didefinisikan sebagai suatu kegiatan penyampaian pesan (komunikasi) dengan menggunakan bahasa tulis sebagai alat atau medianya. Menurut Tarigan (2008), menulis merupakan suatu kegiatan yang produktif dan ekspresif. Dalam kegiatan menulis ini, penulis haruslah terampil memanfaatkan grafelogi, struktur bahasa, kosa kata. Terampil menulis ini tidak akan datang secara otomatis, tetapi harus melalui latihan dan praktik yang banyak dan teratur.

Berdasarkan pendapat di atas dapat disimpulkan bahwa menulis adalah suatu kegiatan penyampaian pesan melalui bahasa tulis sebagai alat atau medianya. Membiasakan siswa terampil menulis tentunya bukan hal yang mudah untuk dilaksanakan. Namun keterampilan menulis biasanya dikembangkan dengan praktik dan banyak latihan. Dengan latihan yang intensif, siswa berlatih dan terus berlatih dan tanpa mereka sadari mereka telah memiliki keterampilan menulis. Proses menulis dititikberatkan pada pengembangan gagasan yang dicurahkan untuk mendapatkan hasil gagasan yang optimal. Pembelajaran menulis bisa diawali dengan penggunaan bahasa secara ekspresif dan imajinatif seperti menulis karya sastra, salah satunya adalah cerpen

Drama merupakan cerita yang menurt wujud fisiknya berbentuk pendek. Ukuran panjang pendeknya suatu cerita memang relatif. Namun pada umumnya cerita pendek merupakan cerita yang habis dibaca sekitar sepuluh menit atau setengah jam. Jumlah katanya sekitar 500-5000 kata (Kosasi, 2012). Selanjutnya menurut Yunus S. , (2015) cerpen merupakan cerita rekaan yang pendek. Ukuran pendek dalam cerpen didasarkan pada ketuntasan membaca cerpen dalam sekali duduk, saat naik bus atau kereta api. Cerita pendek juga menyajikan kesan yang sama secara konsisten hingga cerita berakhir.

Drama dapat terbentuk karena adanya unsur-unsur intrinsik cerita yaitu tema, plot atau alur, penokohan serta perwatakan, latar atau setting. Fenomena yang saat ini terjadi dalam pembelajaran menulis teks drama di sekolah dari hasil observasi dan wawancara pada guru yang mengajar di sekolah tersebut menunjukkan kualitas pembelajaran menulis siswa kelas VII SMP Setia Negara Palembang tergolong masih rendah. Berdasarkan hasil wawancara dengan guru yang mengajar Bahasa Inggris, diperoleh informasi 
bahwa nilai rata-rata kelas untuk materi menulis dalam teks drama hanya mencapai angka 65 (sementara ketuntasan minimal untuk mata pelajaran Bahasa Inggris di SMP adalah 70). Untuk meningkatkan keterampilan menulis dalam teks drama adalah dengan cara memperbaiki proses dalam kegiatan pembelajaran di kelas. Faktorfaktor pendukung pembelajaran guna tercapainya tujuan pengajaran adalah ketepatan penggunaan model pembelajaran, kompetensi guru, dan sarana di dalamnya. Oleh karena itu, guru sebagai tenaga pengajar harus kreatif dan tepat dalam memilih model pembelajaran sehingga pengajaran sastra menjadi menarik dan mudah dipahami oleh siswanya khususnya dalam menulis cerpen.

Hal tersebut dilakukan dalam upaya menumbuhkan minat belajar sehingga potensi dan daya kreativitas siswa dapat tersalurkan dengan baik. Selanjutnya dapat memaksimalkan hasil pembelajaran sesuai dengan yang diharapkan. Dari sekian banyak model yang diperkenalkan salah satunya, model pembelajaran IOC (InsideOutside-Circle). Model pembelajaran IOC pertama kali diperkenalkan oleh Spencer Kagan (1990). Model ini memungkinkan siswa untuk saling berbagi informasi pada waktu yang bersamaan.

Materi pelajaran yang paling cocok digunakan dengan model ini adalah bahan-bahan yang membutuhkan pertukaran pikiran dan informasi antarsiswa. Karakteristik model pembelajaran $10 \mathrm{C}$ merupakan model pembelajaran yang melibatkan siswa untuk membuat kelompok sehingga siswa terlibat aktif dalam komunikasi guna bertukar ide dan pemikiran mengenai materi yang sedang dipelajari. Dengan berkomunikasi dan bertukar pikiran, diharapkan siswa dapat dengan mudah memahami dan menerapkan materi pelajaran yang diberikan oleh guru. Dari pandangan di atas, maka peneliti tertarik untuk mengambil judul dalam penelitian ini yaitu Pengaruh model pembelajaran IOC (inside-outsidecircle) terhadap writing skill dalam teks drama di SMP Setia Negara Palembang. Masalah dalam penelitian ini adalah bagaimanakah Pengaruh model pembelajaran IOC (inside-outside-circle) terhadap writing skill dalam teks drama di SMP Setia Negara Palembang?.. Model pembelajaran merupakan kerangka kerja struktural yang juga dapat digunakan sebagai pemandu 
untuk mengembangkan lingkungan dan aktivitas belajar yang kondusif (Huda, 2016). Sani dan imas kurniasih (2016:18) mengemukakan bahwa model pembelajaran merupakan sebuah prosedur yang sistematis untuk mencapai tujuan belajar. Menurut Joyce dan Weill (Huda, 2016), mendeskripsikan model pembelajaran sebagai rencana atau pola yang dapat digunakan untuk membetuk kurikulum, mendesain materimateri instruksional, dan memandu proses pengajaran di ruang kelas atau di setting yang berbeda.

Dari uraian di atas dapat disimpulkan bahwa model pembelajaran merupakan suatu perencanaan kegiatan pembelajaran agar dapat mengatasi kesulitan dalam proses belajar yang berhubungan dengan pelaksanaan kegiatan belajar-mengajar.

Macam-macam model pembelajaran yaitu sebagai (Suprijono, 2016);
1) Jigsaw
2) Think-Pair-Share
3) Number Heads Together
4) Group Investigation
5) Two Stay Two Stay
6) Make a Match
7) Listening Team
8) Inside-Outside Circle
9) Bamboo Dancing

10) Point-Counter-Point

11) The Power of Two

12) Listening Team

Pada penelitian ini model pembelajaran yang digunakan adalah model pembelajaran IOC (Inside-Outside Circle). Model pembelajaran $10 \mathrm{C}$ pertama kali diperkenalkan oleh Spencer Kagan (1990). Strategi ini memungkinkan siswa untuk saling berbagi informasi pada waktu yang bersamaan. Bahan-bahan pelajaran yang paling cocok digunakan dengan teknik ini adalah bahan-bahan yang membutuhkan pertukaran pikiran dan informasi antarsiswa. Salah satu keunggulan strategi ini adalah adanya struktur yang jelas dan memungkinkan siswa untuk saling berbagi informasi dengan singkat dan teratur. Selain itu, siswa memiliki banyak kesempatan untuk mengolah informasi dan meningkatkan keterampilan berkomunikasi, (Huda, 2016, p. 247).

Menurut (Suprijono, 2016) model pembelajaran $10 \mathrm{C}$ adalah pembelajaran yang diawali dengan pembentukan kelompok dengan tujuan agar siswa dapat bertukar informasi terhadap materi yang diperoleh selama proses belajar. Dengan demikian dapat disimpulkan bahwa model pembelajaran 
IOC adalah model pembelajaran yang menekankan komunikasi antarsiswa dalam belajar karena melibatkan kelompok. Model ini menerapkan bahwa siswa tidak hanya belajar sendiri mendengarkan guru ceramah, tetapi antarsiswa terjalin komunikasi untuk bertukar informasi mengenai materi yang sedang dipelajari agar pemecahan masalah yang terjadi pada materi pelajaran lebih mudah diselesaikan.

Tarigan Yusuf dan Suparno (2007:1.3), menulis didefinisikan sebagai suatu kegiatan penyampaiaan pesan atau komunikasi dengan menggunakan bahasa tulis sebagai sebagai alat atau medianya.

Dalman

(2015:3), mengemukakan menulis ialah suatu kegiatan komunikasi berupa penyampaian pesan (informasi) secara tertulis kepada pihak lain dengan menggunakan bahasa tulis sebaga alat atau medianya. Aktifitas menulis melibatkan melibatkan beberapa unsur, yaitu: penulis sebagai penyampaian pesan, isi tulisan, saluran, atau media, dan pembaca. Sejalan dengan itu Tarigan (1994:3), menjelaskan bahwa menulis merupakan suatu keterampilan berbahasa yang dipergunakan untuk berkomunikasi secara tidak langsung, tidak secara tatap muka dengan orang lain.

\section{Berdasarkan pendapat-pendapat} tersebut dapat disimpulkan bahwa menulis adalah suatu kegiatan berbahasa yang melahirkan pikiran yang dilakukan secara tidak langsung untuk menyampaikan suatu pesan dengan media bahasa tulis. Dikutip dari jurnal oleh Ulumuddin (2005:02) menjelaskan ada berbagai versi pembagian genre (ragam tulisan). Stanley, dkk (1988) membagi genre tulisan dalam:

\section{a. Ragam Tulisan Ekspresi Diri}

Ragam tulisan ekspresi diri bertujuan untuk mengekspresikan perasaan, pikiran, kenangan, dan impian yang bersifat pribadi. Kadang-kadang penulis mengekspresikan persepsi tentang peristiwa atau hal menurut dirinya, menulis kejadian sehari hari yang remeh-remeh, dan pengamatan tentang suatu hal. Ragam tulisan ini biasanya berbentuk catatan harian, autobiografi, dan kisah. Kebiasaan baik untuk mempertajam tulisan ini adalah melakukan observasi dan menulis dalam buku harian.

Ragam tulisan ekspresi diri diantaranya adalah tulisan pribadi (yourself), tulisan tentang kejadian atau peristiwa (incident), dan tulisan tentang 
tahapan dalam kehidupan (stage in your life). Dalam mengekspresikan tulisan yang bersifat pribadi, penulis tidak perlu ragu-ragu (khawatir) dengan bahasa yang digunakan. Tuliskan saja apa yang anda alami dan rasakan dalam bentuk draft. Baca ulang dan sunting. Dengan melakukan kegiatan ini penulis akan memiliki cerita panjang.

Misalnya, tulisan tentang perjalanan perkawinan, perjalanan pendidikan, kisah sedih dan ceria, kisah indah dan mencekam, yang bersifat personal. Anda bisa bercerita tentang diri anda atau anda dapat bercerita tentang orang lain menurut pandangan anda. Dalam Artikel Slilit Sang Kiai (Najib, 1990) misalnya, dia secara pribadi berpendapat hanya karena slilit (sisa daging yang terjepit di gigi) seorang Kiai ketika meninggal harus menunggu di pintu surga karena ia mengambil sayatan bambu pagar orang lain untuk mencongkel slilitnya tanpa ijin pemilik pagar.

\section{b. Ragam Tulisan Eksplorasi (Pemaparan)}

Ragam tulisan eksplorasi (pemaparan) bertujuan untuk menjelajah tempat, masalah (kasus) sejelasjelasnya agar pembaca seolah-olah ikut melihat dan merasakan berdasarkan penalaran yang dibuat oleh penulis. Oleh karena itu, dalam menulis jenis karangan ini, penulis harus mampu menghidupkan objek yang kita lukiskan sehiduphidupnya sehingga pembaca seolah-olah mendengar apa yang kita dengar dan melihat apa yang kita lihat, dan dapat merasakan apa yang kita rasakan.

Menurut Yunus S. d., (2009)
untuk mendeskripsikan suatu tempat
atau peristiwa, deskripsi sering
digunakan sebagai alat bantu bentuk
karangn lain, yang tujuannya untuk
menghidupkan karangan dan
menghindarkan kebosanan pembaca,
serta menambah kejelasan dan
keyakinan pembaca.

\section{c. Ragam Tulisan Eksplanasi (Penjelasan)}

Ragam tulisan ini meliputi ragam tulisan di media massa (majalah/koran) dan tulisan hasil penelitian atau riset. Ragam tulisan di media massa dapat disebut juga varian bahasa Jurnalistik, yaitu ragam bahasa yang digunakan untuk menulis di surat kabar baik dalam rubrik berita (news) berita kisah (fetures) dan opini atau pendapat. Kekhasan ragam ini terletak pada pemakaian leksikon dan kesederhanaan struktur bahasanya. Dalam ragam tulisan ini dikenal istilah KISS (Keep it simple and 
short). Artinya, dalam menulis usahakan singkat dan pendek. Rumusnya sedikit koma banyak titik.

Ragam eksplanasi dikenal juga dengan ragam eksposisi yaitu tulisan yang bertujuan untuk memberi tahu, mengupas, menguraikan, atau menerangkan sesuatu yang dapat berupa (a) data faktual, misalnya tentang suatu kondisi yang benar-benar terjadi, tentang bagaimana sesuatu bekerja. Misalnya, bagaimana sistem motor bakar bekerja atau sistem pembakaran tubuh. Eksposisi juga berisi suatu analisis atau suatu penafsiran yang objektif terhadap seperangkat fakta. Misalnya, mengapa pendidikan di Indonesia tertinggal dibandingkan dengan pendidikan di Malaysia atau Singapura. Mengapa anak SD, SMP, SMA diwajibkan mengikuti standar kelulusan dengtan ujian nasional sedangkan mahasiswa di program studi tidak dituntut standar kelulusan dengan ujian nasional? Mengapa mahasiswa yang masuk SPMB dengan mahasiswa yang masuk jalur reguler diberi perlakuan yang sama dalam proses dan hasil pendidiklan?. Mengapa banyak mahasiswa pascasarjana dari Instansi kedinasan memperoleh perlakuan berbeda dengan mahasiswa reguler dalam hal kelulusan?. Mengapa IPDN menyelenggarkan pendidikan bergaya semimiliter? Berbagai pertanyaan tersebut, dapat dianalisis dengan tulisan eksposisi. Ragam tulisan eksplanasi atau eksposisi dapat berupa tulisan hasil penelitian. Artikel konseptual dan atau artikel hasil penelitian dapat ditulis dengan ragam tulisan eksplanasi atau eksposisi. Pengembangan karangan eksplanasi atau eksposisi bergantung pada dua hal (1) sifat penjelasan yang akan penulis berikan dan (2) tujuan yang ingin dicapai.

\section{d. Ragam Tulisan Persuasi}

Ragam tulisan persuasi bertujuan mengkomunikasikan persoalan antara penulis kepada pembaca agar pembaca menjadi yakin terhadap apa yang dikomunikasikan. Ragam tulisan persuasi-ada yang menyebut argumentasi- biasa ditulis oleh editorial surat kabar yang bertujuan membujuk (persuade). Politisi membujuk konstituennya, pendeta dan ustadz membujuk atau meyakinkan jemaatanya, pengiklan membujuk calon konsumennya.

Tulisan argumentasi atau persuasi bertujuan untuk memberi alasan, untuk memperkuat atau menolak suatu pendapat atau pendirian atau gagasan. Dalam setiap karangan 
argumentasi atau persuasi selalu terdapat alasan (argumen) atau bantahan yang memperkuat atau menolak sesuatu sedemikian rupa guna mempengaruhi keyakinan pembaca.

\section{B. METODE PENELITIAN}

Riduwan (2015, p. 50), menyatakan metode eksperimen adalah suatu penelitian yang berusaha mencari pengaruh variabel yang lain dalam kondisi yang terkontrol secara ketat. Metode yang digunakan dalam penelitian ini adalah metode eksperimen, dengan desain eksperimen Posttest-Only Control Design. Untuk lebih jelasnya dapat dilihat pada gambar 1 di bawah ini.

\begin{tabular}{|lll|}
\hline$R$ & $X$ & $O_{2}$ (Eksperimen) \\
$R$ & & $O_{4}$ (Control) \\
\hline
\end{tabular}

(Sumber: Sugiyono, 2011:85)

Dalam desain ini terdapat dua kelompok yang masing-masing dipilih secara random $(\mathrm{R})$. Kelompok pertama diberi perlakuan $(X)$ dan kelompok lain tidak. Kelompok yang diberi perlakuan disebut kelompok eksperimen $\left(O_{1}\right)$ dan kelompok yang tidak diberi perlakuan disebut kelompok kontrol $\left(\mathrm{O}_{2}\right)$. Metode yang digunakan dalam penelitian ini adalah metode eksperimen. Dari uraian tersebut, maka hal ini bertujuan untuk mengetahui dan mendeskripsikan Pengaruh model pembelajaran IOC (inside-outside-circle) terhadap writing skill dalam teks drama di SMP Setia Negara Palembang.

\section{HASIL DAN PEMBAHASAN}

Dalam menentukan nilai tes, peneliti membagi penelitian menulis cerita pendek menjadi 6 aspek yaitu, penggunaan alur atau plot, penggambaran tokoh dan penokohan, pedeskripsian latar, penggunaan gaya bahasa, penggunaan sudut pandang dan tema cerita drama. Untuk lebih jelasnya dapat dilihat pada tabel sebagai berikut. 
TABEL 3

\section{KRITERIA PENILAIAN MENULIS CERITA PENDEK}

\begin{tabular}{|c|c|c|c|c|}
\hline No. & $\begin{array}{c}\text { Aspek } \\
\text { yang Dinilai }\end{array}$ & Rincian Penilaian & $\begin{array}{l}\text { Rentang } \\
\text { skor }\end{array}$ & $\begin{array}{c}\text { Keteranga } \\
\mathrm{n}\end{array}$ \\
\hline \multirow[t]{4}{*}{1} & \multirow[t]{4}{*}{$\begin{array}{l}\text { Penggunaan } \\
\text { Alur atau Plot }\end{array}$} & $\begin{array}{l}\text { Permainan alur tidak menarik, tidak ada } \\
\text { tegang dan kejutan serta pembayangan yang } \\
\text { akan terjadi. }\end{array}$ & $1-5$ & Kurang \\
\hline & & $\begin{array}{l}\text { Permaianan alur kurang menarik, kurang ada } \\
\text { tegang dan kejutan serta pembayangan yang } \\
\text { akan terjadi. }\end{array}$ & $6-10$ & $\begin{array}{l}\text { Kurang } \\
\text { Baik }\end{array}$ \\
\hline & & $\begin{array}{l}\text { Permainan alur cukup menarik, cukup tegang } \\
\text { dan kejutan serta pembayangan yang akan } \\
\text { terjadi. }\end{array}$ & $\begin{array}{c}11- \\
15\end{array}$ & Baik \\
\hline & & $\begin{array}{l}\text { Permainan alur menarik, ada tegang dan } \\
\text { kejutan serta pembayangan yang akan terjadi. }\end{array}$ & $\begin{array}{c}16- \\
20\end{array}$ & $\begin{array}{l}\text { Sangat } \\
\text { Baik }\end{array}$ \\
\hline \multirow[t]{4}{*}{2} & \multirow[t]{4}{*}{$\begin{array}{l}\text { Penggambaran } \\
\text { Tokoh dan } \\
\text { Penokohan }\end{array}$} & $\begin{array}{l}\text { Pelukisan watak tokoh tidak tajam dan nyata, } \\
\text { tokoh tidak mampu membawa pembaca } \\
\text { mengalami peristiwa yang terjadi. }\end{array}$ & $1-5$ & Kurang \\
\hline & & $\begin{array}{l}\text { Pelukisan watak tokoh kurang tajam dan } \\
\text { nyata, tokoh tidak mampu membawa pembaca } \\
\text { mengalami peristiwa yang terjadi. }\end{array}$ & $6-10$ & $\begin{array}{l}\text { Kurang } \\
\text { Baik }\end{array}$ \\
\hline & & $\begin{array}{l}\text { Pelukisan watak tokoh cukup tajam tajam dan } \\
\text { nyata, tokoh tidak mampu membawa pembaca } \\
\text { mengalami peristiwa yang terjadi. }\end{array}$ & $\begin{array}{c}11- \\
15\end{array}$ & Baik \\
\hline & & $\begin{array}{l}\text { Pelukisan watak tokoh tajam dan nyata, tokoh } \\
\text { tidak mampu membawa pembaca mengalami } \\
\text { peristiwa yang terjadi. }\end{array}$ & $\begin{array}{c}16- \\
20\end{array}$ & $\begin{array}{l}\text { Sangat } \\
\text { Baik }\end{array}$ \\
\hline \multirow[t]{4}{*}{3} & \multirow[t]{4}{*}{$\begin{array}{l}\text { Pendeskripsian } \\
\text { latar }\end{array}$} & $\begin{array}{l}\text { Tidak tepat dalam memilih tempat yang } \\
\text { mengukuhkan terjadinya peristiwa, tidak tepat } \\
\text { memilih waktu yang sesuai dengan peristiwa } \\
\text { dalam cerita, dan tidak tepat menggambarkan } \\
\text { suasana yang mendukung peristiwa. }\end{array}$ & $1-5$ & Kurang \\
\hline & & $\begin{array}{l}\text { Kurang tepat dalam memilih tempat yang } \\
\text { mengukuhkan terjadinya peristiwa, kurang } \\
\text { tepat memilih waktu yang sesuai dengan } \\
\text { peristiwa dalam cerita, dan kurang tepat } \\
\text { menggambarkan suasana yang mendukung } \\
\text { peristiwa. }\end{array}$ & $6-10$ & $\begin{array}{l}\text { Kurang } \\
\text { Baik }\end{array}$ \\
\hline & & $\begin{array}{l}\text { Cukup tepat dalam memilih tempat yang } \\
\text { mengukuhkan terjadinya peristiwa, cukup } \\
\text { tepat memilih waktu yang sesuai dengan } \\
\text { peristiwa dalam cerita, dan cukup tepat } \\
\text { menggambarkan suasana yang mendukung } \\
\text { peristiwa. }\end{array}$ & $\begin{array}{c}11- \\
15\end{array}$ & Baik \\
\hline & & $\begin{array}{l}\text { Tepat dalam memilih tempat yang } \\
\text { mengukuhkan terjadinya peristiwa, tepat } \\
\text { memilih waktu yang sesuai dengan peristiwa }\end{array}$ & $\begin{array}{c}16- \\
20\end{array}$ & $\begin{array}{l}\text { Sangat } \\
\text { Baik }\end{array}$ \\
\hline
\end{tabular}




\begin{tabular}{|c|c|c|c|c|}
\hline & & $\begin{array}{l}\text { dalam cerita, dan tepat menggambarkan } \\
\text { suasana yang mendukung peristiwa. }\end{array}$ & & \\
\hline \multirow[t]{4}{*}{4} & \multirow[t]{4}{*}{$\begin{array}{l}\text { Penggunaan } \\
\text { Gaya Bahasa }\end{array}$} & $\begin{array}{l}\text { Tidak tepat dalam memilih gaya bahasa yang } \\
\text { mengandung unsur, emotif dan bersifat } \\
\text { konotatif dan tidak tepat dalam memilih } \\
\text { ungkapan yang mewakili sesuatu yang } \\
\text { diungkapkan. }\end{array}$ & $1-4$ & Kurang \\
\hline & & $\begin{array}{l}\text { Kurang tepat dalam memilih gaya bahasa } \\
\text { yang mengandung unsur, emotif dan bersifat } \\
\text { konotatif dan kurang tepat dalam memilih } \\
\text { ungkapan yang mewakili sesuatu yang } \\
\text { diungkapkan. }\end{array}$ & $5-8$ & $\begin{array}{l}\text { Kurang } \\
\text { Baik }\end{array}$ \\
\hline & & $\begin{array}{l}\text { Cukup tepat dalam memilih gaya bahasa } \\
\text { yang mengandung unsur, emotif dan bersifat } \\
\text { konotatif dan cukup tepat dalam memilih } \\
\text { ungkapan yang mewakili sesuatu yang } \\
\text { diungkapkan. }\end{array}$ & $9-12$ & Baik \\
\hline & & $\begin{array}{l}\text { Tepat dalam memilih gaya bahasa yang } \\
\text { mengandung unsur, emotif dan bersifat } \\
\text { konotatif dan Tepat dalam memilih ungkapan } \\
\text { yang mewakili sesuatu yang diungkapkan. }\end{array}$ & $\begin{array}{c}13- \\
15\end{array}$ & $\begin{array}{l}\text { Sangat } \\
\text { Baik }\end{array}$ \\
\hline \multirow[t]{4}{*}{5} & \multirow[t]{4}{*}{$\begin{array}{l}\text { Penggunaan } \\
\text { Sudut Pandang }\end{array}$} & $\begin{array}{l}\text { Tidak baik dalam memberikan perasaan } \\
\text { kedekatan tokoh, tidak baik dalam } \\
\text { menjelaskan kepada pembaca siapa yang } \\
\text { dituju dan menunjukkan perasaan tokoh } \\
\text { kepada pembaca. }\end{array}$ & $1-4$ & Kurang \\
\hline & & $\begin{array}{l}\text { Kurang baik dalam memberikan perasaan } \\
\text { kedekatan tokoh, kurang baik dalam } \\
\text { menjelaskan kepada pembaca siapa yang } \\
\text { dituju dan menunjukkan perasaan tokoh } \\
\text { kepada pembaca. }\end{array}$ & $5-8$ & $\begin{array}{l}\text { Kurang } \\
\text { Baik }\end{array}$ \\
\hline & & $\begin{array}{l}\text { Cukup baik dalam memberikan perasaan } \\
\text { kedekatan tokoh, cukup baik dalam } \\
\text { menjelaskan kepada pembaca siapa yang } \\
\text { dituju dan menunjukkan perasaan tokoh } \\
\text { kepada pembaca. }\end{array}$ & $9-12$ & Baik \\
\hline & & $\begin{array}{l}\text { Baik dalam memberikan perasaan kedekatan } \\
\text { tokoh, Baik dalam menjelaskan kepada } \\
\text { pembaca siapa yang dituju dan menunjukkan } \\
\text { perasaan tokoh kepada pembaca. }\end{array}$ & $\begin{array}{c}13- \\
15\end{array}$ & $\begin{array}{l}\text { Sangat } \\
\text { Baik }\end{array}$ \\
\hline \multirow[t]{2}{*}{6} & \multirow[t]{2}{*}{ Tema Cerita } & $\begin{array}{l}\text { Tidak baik dalam mendeskripsikan tema yang } \\
\text { terkandung dalam cerita dan ditawarkan } \\
\text { kepada pembaca, tidak baik dalam menyajikan } \\
\text { tema dari kesimpulan keseluruhan cerita, tema } \\
\text { tidak mengangkat masalah-masalah } \\
\text { kehidupan. }\end{array}$ & $1-3$ & Kurang \\
\hline & & $\begin{array}{l}\text { Kurang baik dalam mendeskripsikan tema } \\
\text { yang terkandung dalam cerita dan ditawarkan } \\
\text { kepada pembaca, kurang baik dalam } \\
\text { menyajikan tema dari kesimpulan keseluruhan }\end{array}$ & $4-6$ & $\begin{array}{l}\text { Kurang } \\
\text { Baik }\end{array}$ \\
\hline
\end{tabular}




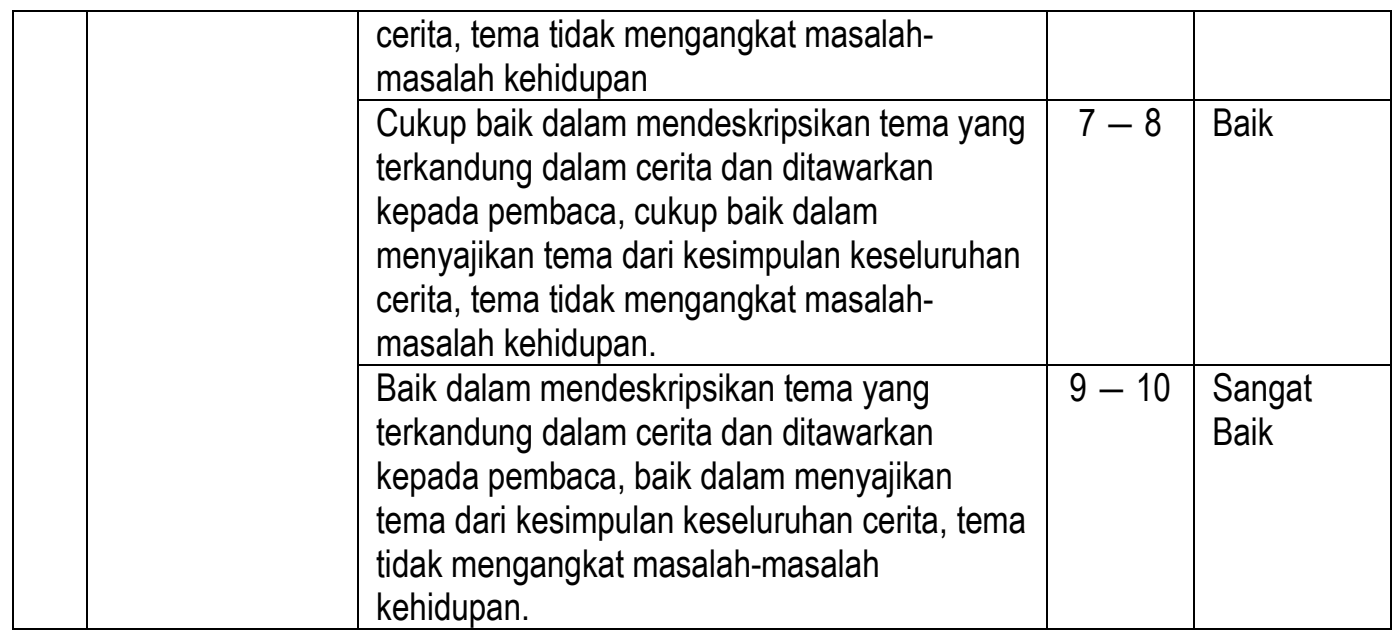

Sumber : (Modifikasi Nurgiantoro, 2016:277).

Nilai : $\frac{\text { Jumlah skor yang diperoleh }}{\text { Jumlah skor maksimal }} \times 100$

Teknik analisis data merupakan cara yang digunakan untuk mengelola data-data yang terkumpul dan diklasifikasikan sesuai tujuan penelitian. Data hasil belajar yang telah didapat, diperiksa dinilai, kemudian dianalisis untuk melihat daya serap setelah diterapkan pembelajaran tentang menulis drama model pembelajaran IOC (InsideOutside Circle). Langkah-langkah yang harus dilakukan menganalisis data tes hasil belajar pembelajaran Bahasa Inggris dalam menulis cerita pendek.

1) Melihat siswa dalam menulis drama

2) Memberikan skor dari hasil menulis drama

3) Membuat analisis dari hasil belajar siswa.
Nilai akhir yang diperoleh siswa diolah dengan menggunakan rumus sebagai berikut.

Nilai akhir $=$

$\frac{\text { pemerolehan skor }}{\text { skor maksimal }} x$ skor ideal 100

Dari analisis hasil belajar tersebut dicari rata-rata meannya.

$\bar{x}=\frac{\sum x_{i}}{n}$

(Sudjana, 2005, p. 67)

$\bar{x} \quad=$ Nilai rata-rata

$\sum x_{i}=$ Jumlah nilai siswa

$\mathrm{n}=$ = Jumlah siswa

Selanjutnya hasil belajar siswa tersebut di persentasikan pada tabel penilaian dibawah ini:

\section{TABEL 4}

Kategori Hasil Belajar Siswa 


\begin{tabular}{|c|c|}
\hline $\begin{array}{c}\text { Rata-Rata Nilai } \\
\text { Hasil Belajar }\end{array}$ & $\begin{array}{c}\text { Kategori Hasil } \\
\text { Belajar Siswa }\end{array}$ \\
\hline $86-100$ & Amat baik \\
$71-85$ & Baik \\
$56-70$ & Cukup \\
$41-55$ & Kurang \\
$\leq 40$ & Sangat kurang \\
\hline
\end{tabular}

Setelah tes dilakukan, selanjutnya menghitung normalitas dan pengujian hipotesis sebagai berikut.

4) Uji Homogenitas

Uji Homogenitas dilakukan untuk membuktikan variabel homogen atau tidak. Pengujian homogenitas varians menggunkan uji $\mathrm{F}$ dengan rumus.

$\mathrm{F}=\frac{\text { Varian terbesar }}{\text { Varian terkecil }}$

(Sudjana, 2005, p. 250)

5) Uji Normalitas

Menguji normalitas data menggunakan rumus kemencengangan kurva yaitu rumus efisiensi kemiringan pearson.

$$
\mathrm{Km}: \frac{\bar{X}-M o}{S}
$$

(Sudjana, 2005, p. 109)

\section{Keterangan:}

$\mathrm{Km}=$ kemiringan kurva

$\bar{X} \quad=$ rata-rata

Mo = modus
S = simpangan baku

Data dikatakan nomal apabila KM terletak antara -1 sampai +1 ($1<\mathrm{Km}<=1)$.

6) Uji Hipotesis

$$
t=\frac{\left(\overline{x_{1}}-\overline{x_{2}}\right)}{s_{p} \sqrt{\left(\frac{1}{n_{1}}\right)+\left(\frac{1}{n_{2}}\right)}}
$$

Guna membuktikan hipotesis yang telah dirumuskan dan untuk mendapatkan sesuatu kesimpulan maka data tes yang diberikan kepada siswa yang diajar dengan model pembelajaran konvensional dianalisis dengan uji-t dengan rumus sebagai berikut.

$$
t=\frac{\left(\overline{x_{1}}-\overline{x_{2}}\right)}{s_{p} \sqrt{\left(\frac{1}{n_{1}}\right)+\left(\frac{1}{n_{2}}\right)}}
$$

(Sudjana, 2005, p. 239)

$$
\text { Dengan kriteria tolak } \mathrm{H} 0 \text { Jika } t
$$

Hitung $>\mathrm{t}$

$$
s 2=\sqrt{\frac{\left(n_{1}-1\right) s_{1}^{2}+\left(n_{2}-1\right) s_{2}^{2}}{n_{1}+n_{2}-2}}
$$

$x_{1}=$ Rata-rata nilai kels ekperimen

$x_{2}=$ Rata-rata nilai kelas kontrol

$\mathrm{n}_{1}=$ Sampel kelas eksperimen

$\mathrm{n}_{2}=$ Sampel kelas kontrol 
$\mathrm{S}_{1}=$ Simpangan baku siswa kelas

eksperimen

$\mathrm{S}_{2}=$ simpangan baku siswa kelas

kontrol.

\section{Kriteria Pengujian Hipotesis}

Uji hipotesis dilakukan untuk mengetahui apakah penggunaan metode Hypnoteaching memberika atau tidak memberikan pengaruh yang positif terhadap Penerapan model pembelajaran IOC (inside-outside-circle) terhadap writing skill dalam teks drama di SMP Setia Negara Palembang. Hipotesis yang diuji kebenarannya apabila data yang diperoleh bedistribusi normal maka digunakan rumus statistik uji-t (t-tes). Kriteria pengujian hipotesis yang digunakan sebagai berikut.

Ho : Tidak ada pengaruh model pembelajaran IOC (inside-outsidecircle) terhadap writing skill dalam teks drama di SMP Setia Negara Palembang $\mathrm{Ha}$ : Ada pengaruh Penerapan model pembelajaran IOC (inside-outside-circle) terhadap writing skill dalam teks drama di SMP Setia Negara Palembang.

Adapun kriteria pengujian hipotesis ini adalah tolak Ho Jika $t_{b i t}>\mathrm{t}$ (1-a) dimana distribusi t yang digunakan mempunyai dk- $n_{1}+n_{2}-2$ dengan taraf nyata $a=5 \%$ dalam hal ini $\mathrm{Ho}$ diterima (Sudjana, 2005, p. 243).

Kriteria pengujian Hipotesis dalam penelitian ini sebagai berikut.

a) Ho diterima bila

$t_{\text {hitung }}<t_{\text {tabel }}$ atau $t_{\text {hitung }}$

berarti Ha ditolak.

b) Ha diterima bila

$t_{\text {hitung }} t_{\text {tabel }}$ atau $t_{\text {hitung }}$ berarti

Ho ditolak

\section{Pembahasan}

Penelitian ini bertujuan untuk mengetahui dan mendeskripsikan ada atau tidaknya pengaruh model pembelajaran IOC (inside-outside-circle) terhadap writing skill dalam teks drama di SMP Setia Negara Palembang. Penelitian ini dilakukan pada tanggal 5 10 Maret 2020.

Metode pembelajaran IOC diterapkan pada kelas eksperimen yaitu kelas VII C yang terdiri atas 30 siswa. Kelas ekperimen memperoleh skor 2345 dengan rata-rata 78 . Sedangkan kelas kontrol yaitu kelas VII A dengan jumlah 25 siswa memperoleh skor 1630 dengan rata-rata 65 , dapat dilihat dari rata-rata setiap kelas jelas sangat berbeda, di mana rata-rata nilai eksperimen lebih 
tinggi daripada kelas kontol yang hanya menggunakan model pembelajaran konvensional. Selain itu berdasarkan perhitungan di atas diperoleh $t_{\text {hitung }}$ sebesar 5,38 sedangkan $t_{\text {tabel }} 1,67412$.

Berdasarkan kriteria pengujian hipotesis, jika $t_{\text {hitung }} \leq t_{\text {tabel }}$ berarti $\mathrm{Ha}$ ditolak Ho diterima akan tetapi $t_{\text {hitung }} \geq t_{\text {tabel }}$ maka Ha diterima dan Ho ditolak. Artinya metode $10 \mathrm{C}$ mempengaruhi kemampuan siswa dalam menulis drama siswa kelas VII SMP Setia Negara Palembang. Salah satu penyebab hasil belajar kelas eksperimen lebih baik adalah adanya penerapan metode IOC yang membuat siswa menjadi lebih aktif, kreatif, lebih inisiatif, dan memiliki kepercayaan diri yang tinggi. Seiring dengan hal tersebut, maka hasil belajar siswa meningkat dan lebih optimal. Dengan demikian hipotesis yang menyatakan adanya pengaruh penerapan metode IOC terhadap Kemampuan Menulis teks drama Siswa Kelas VII SMP Setia Negara sangat baik dan terbukti kebenarannya.

\section{SIMPULAN}

Berdasarkan hasil tes akhir menulis cerita pendek diperoleh rata-rata kelompok eksperimen yang diberikan perlakuan dengan menggunakan metode IOC (Inside-Outside-Circle) yaitu sebesar 78. Sementara rata-rata kelompok kontrol yang diberikan perlakuan model pembelajaran konvensional yaitu sebesar 65 . Berdasarkan hasil rata-rata tes kelompok eksperimen dan kelompok kontrol ternyata diperoleh bahwa ratarata kelompok eksperimen lebih tinggi daripada rata-rata kelompok kontrol. Berdasarkan tabel distribusi - $\mathrm{t}$ (Riduwan, 2015, p. 235) dengan $\mathrm{dk}=n_{1}+$ $n_{2}-2=30+25-2=53$ dan $\mathrm{a}=0,05$, diperoleh $t_{\text {hitung }}=5,38$ dan $t_{\text {tabel }}=$ 1,67412. Hal ini menunjukkan bahwa $t_{\text {hitung }} \geq t_{\text {tabel }}$ atau 5,38 $\geq 1,67412$. Dengan demikian dapat dikatakan bahwa $\mathrm{H}_{\mathrm{o}}$ ditolak dan $\mathrm{H}_{\mathrm{a}}$ diterima, berarti penerapan metode $10 \mathrm{C}$ terhadap keterampilan menulis teks drama siswa kelas VII SMP Setia Negara Palembang. Hal ini berarti bahwa hipotesis pada penelitian ini terbukti kebenarannya. 


\section{DAFTAR PUSTAKA}

Arikunto, S. (2006). Prosedur Penelitian Suatu Pendekatan Praktik . Jakarta: PT Rineka Cipta.

Dalman. (2015). Keterampilan Menulis. Jakarta. Raja Grafindo.

Hassan, M. A., Suleiman, M. S., \& Najib, N. M. 1990. Improvement of the in vitro dissolution characteristics of famotidine by inclusion in $\beta$-cyclodextrin. Int $\mathrm{J}$. of pharmaceutics, 58(1), 19-24

Huda, M. (2016). Model-Model Pengajaran dan Pembelajaran. Yogyakarta: Pustaka Belajar.

Kosasi. (2012). Dasar-Dasar Keterampilan Bersastra. Bandung: Yrama Widya.

Kurniasih, I., \& Berlin, S. (2016). Ragam Pengembangan Model Pembelajaran untuk Peningkatan Profesionalitas Guru. Surabaya. Kata Pena.

Nurgiyantoro, B. (2016). Sastra Anak. Yogyakarta. Gadjah Mada University Press.

Pine, H, Stanley. (1988). Organic Chemistry. Penerjemah: Rohyati, Joedodibroto. Santi, W. Purbo, hadiwidjojo. Bandung: ITB.

Riduwan. (2015). Belajar Mudah Penelitian Guru-Karyawan Penelitian Pemula. Bandung: Alfabeta.

Sudjana. (2005). Metoda Statistika. Bandung: PT. Tarsito Bandung.

Sugiyono. (2011). Metode Penelitian Administrasi. Bandung: Alfabeta.

Suparno \& Yunus, M. (2007). Keterampilan Dasar Menulis. Jakarta. Universitas Terbuka.

Suprijono, A. (2016). Cooperative Learning. Yogyakarta: Pustaka Belajar.

Tarigan, H.G. (2008). Menulis Sebagai Suatu Keterampilan Berbahasa. Bandung. Angkasa

Tarigan, H. G. (2008). Menulis. Bandung: Angkasa.

Yunus, S. (2015). Kompetensi Menulis Kreatif. Bogor: Ghalia Indonesia.

Yunus, S. d. (2009). Keterampilan Dasar Menulis. Jakarta: Universitas Terbuka. 